\section{Growth Characteristics and Ascorbic Acid Content of Several Genotypes of Jute (Corchorus olitorius Linn)}

\author{
M.J. Dinakin and S.A. Ayanlaja ${ }^{1}$ \\ National Horticultural Research Institute, Ibadan and Ogun State University, \\ Ago-Iwoye, Nigeria
}

Additional index words. leafy vegetable, potherb

Starchy staple foods of the tropical countries are usually eaten with leafy vegetables, such as jute. It is grown in Africa, the Caribbean, and tropical Asia for the preparation of draw-soup (Grubben, 1977; Purseglove, 1972). There is considerable diversity among accessions, with varying leaf shapes being important differentiating characteristics between cultivars (Akoroda, 1985). If a visible cultivar characteristic could be associated with edible leaf yield and ascorbic acid (AA) content, it could act as an indicator for identifying cultivars with the desirable qualities.

We describe characteristics of some Nigerian jute cultivars and attempted to associate some visible properties with yield potential and AA concentration and determine the appropriate time of harvest to optimize AA content.

Seedlots of eight accessions of jute were separately steeped in hot water (100C) for 10 sec to break dormancy. The seeds were airdried and sown $2 \mathrm{~cm}$ deep in an open field.

Received for publication 30 May 1995. Accepted for publication 30 May 1995. This paper is being published without the authors' final review because attempts to correspond with them have been unsuccessful. The cost of publishing this paper was defrayed in part by the payment of page charges. Under postal regulations, this paper therefore must be hereby marked advertisement solely to indicate this fact.

${ }^{1}$ To whom reprint requests should be addressed. Current address: Ogun State Univ., PMB2002, AgoIwoye, Nigeria.
Each accession was planted in $1 \times 1.5$-m plots with four replications with spacing at $75 \mathrm{~cm}$ between rows and $10 \mathrm{~cm}$ within rows.

The soil is classified as Ferric Luvisol and Oxic Paleustalf. The surface soil (0 to $15 \mathrm{~cm}$ ) is well-drained and is made up of $68 \%$ sand, $20 \%$ silt, and $12 \%$ clay, with a moisture retention of $17 \%$ at $30 \mathrm{kPa}$. The surface soil had $2.0 \%$ organic $\mathrm{C}$, with a cation exchange capacity of $13.9 \mathrm{me} / 100 \mathrm{~g}$.

Potassium, $\mathrm{Mg}$, and $\mathrm{Ca}$ contents were 0.6, a $\mathrm{pH}$ of 6.2 at a 1 soil : 2 water ratio. Eleven characteristics of each of the accessions were evaluated over two seasons at Ibadan $\left(7^{\circ} 25^{\wedge} \mathrm{N}\right.$, $\left.3^{\circ} 25^{\prime} \mathrm{E}\right)$. In each season, 5 and 8 weeks after seeding, measurements or observations made included plant height; leaf shape; appearance; color; length and width; root length; dry weight (g/plant) of leaves, stems, and roots; and AA concentration of the edible portion (leaf). AA was determined on fresh leaf samples (with correction for moisture content) by the 2,6dichloroindophenol method. The vitamin was extracted and titration performed in the presence of $\mathrm{HPO}_{3}-\mathrm{HOAC}-\mathrm{H}_{2} \mathrm{SO}_{4}$, according to the procedure of the Association of Official Analytical Chemists (1970).

After plant samples had been dried at $80 \mathrm{C}$ overnight, dry weights of the stem, roots, and leaves were determined. Root length was determined by measuring each root strand with a ruler.

Mean separation was by Duncan's multiple range test at $P \leq 0.05$ following analysis of variance. 3.8 , and $9.3 \mathrm{me} / 100 \mathrm{~g}$, respectively, and with
Leaves were either serrated or deeply serrated (Table 1). They were simple and entire, with crenate margins in the serrated type but lobed with serrated margins in those deeply serrated. The leaf length : width ratio was consistent within a given cultivar and ranged between 1.58 to 1.72 , with a mean of 1.62 in the deeply serrated leaves, while the range was between 1.65 and 2.50, with a mean of 2.05 in the serrated type. The average dry weight of edible leaves (economic harvest) was 11.0 and $7.9 \mathrm{~g} /$ plant for the serrated and deeply serrated types, respectively. Thus, the serrated type has significantly higher yield potential. The roots of the serrated type were more vigorous.

Average root length and dry weight in the serrated type were $17.2 \mathrm{~cm}$ and $2.3 \mathrm{~g} / \mathrm{plant}$, respectively, compared to $14.0 \mathrm{~cm}$ and $1.2 \mathrm{~g} /$ plant for the deeply serrated type. Thus, the serrated type may explore a greater soil volume and, therefore, yield more than the deeply serrated type. In addition, the serrated types were taller, with an average height of $40.4 \mathrm{~cm}$ compared with $34.5 \mathrm{~cm}$ for those deeply serrated and, therefore, can bear more leaves. AA concentrations of very glossy leaves were 25.5 and $117 \mathrm{mg} / 100 \mathrm{~g}$ at 5 and 8 weeks after seeding, while those of nonglossy leaves were 37.8 and $152 \mathrm{mg} / 100 \mathrm{~g}$, respectively. Thus, at similar ages, nongloss leaves contained more AA than very glossy leaves. Leaf shape notwithstanding, nonglossy leaves accumulated $48 \%$ and $30 \%$ more AA than the very glossy leaves at 5 and 8 weeks of age, respectively.

AA content of the leaves was much higher at 8 weeks (mean $136 \mathrm{mg} / 100 \mathrm{~g}$ ) than at 5 weeks (mean $36.8 \mathrm{mg} / 100 \mathrm{~g}$ ). Thus, Corchorus rapidly forms AA between 5 and 8 weeks after seeding, with 8 weeks appearing to be a more desirable harvesting age. Serrated Corchorus cultivars with nonglossy leaves seem to possess desirably high yield potential and a high AA content.

\section{Literature Cited}

Akoroda, M.O. 1985. Morphotype in Nigerian landraces of Corchorus olitorius. J. Hort. Sci. 60:557562.

Grubben, G.J. 1977. Tropical vegetables and their genetic resources. Rome IBPGRP p. 91-103.

Purseglove, J. 1971. Tropical crops. Longman, London.

Table 1. Growth characteristics and ascorbic acid (AA) concentration of several jute genotypes. ${ }^{\mathrm{z}}$

\begin{tabular}{|c|c|c|c|c|c|c|c|c|c|c|c|c|}
\hline \multirow{3}{*}{$\begin{array}{l}\text { Accession } \\
\text { no. } \\
\text { (NH87-) }\end{array}$} & \multirow{3}{*}{$\begin{array}{c}\text { Plant } \\
\text { ht } \\
(\mathrm{m})\end{array}$} & \multicolumn{5}{|c|}{ Leaf ${ }^{y}$} & \multirow{3}{*}{$\begin{array}{l}\text { Root } \\
\text { length } \\
(\mathrm{m})\end{array}$} & \multirow{2}{*}{\multicolumn{3}{|c|}{$\begin{array}{l}\text { Dry wt } \\
\text { (g/plant) }\end{array}$}} & \multirow{2}{*}{\multicolumn{2}{|c|}{$\begin{array}{c}\begin{array}{c}\text { AA concn } \\
(\mathrm{mg} / 100 \mathrm{~g})\end{array} \\
\text { Weeks }^{\mathrm{x}}\end{array}$}} \\
\hline & & \multirow[b]{2}{*}{ Shape } & \multirow[b]{2}{*}{ Gloss } & \multirow[b]{2}{*}{ Color } & \multirow{2}{*}{$\begin{array}{c}\text { Length } \\
(\mathrm{m})\end{array}$} & \multirow{2}{*}{$\begin{array}{l}\text { Width } \\
(\mathrm{m})\end{array}$} & & & & & & \\
\hline & & & & & & & & Leaf & Stem & Root & 5 & 8 \\
\hline$\overline{\mathrm{C} 02}$ & $336 c$ & 1 & 3 & 2 & $68 \mathrm{c}$ & $43 \mathrm{c}$ & $127 \mathrm{c}$ & $6.9 \mathrm{c}$ & $9.4 \mathrm{~cd}$ & $0.85 \mathrm{~d}$ & 39 & 178 \\
\hline $\mathrm{C} 04$ & $322 \mathrm{c}$ & 1 & 3 & 2 & $106 \mathrm{a}$ & $45 \mathrm{bc}$ & $142 \mathrm{de}$ & $7.8 \mathrm{bc}$ & $7.3 \mathrm{~d}$ & $1.13 \mathrm{~d}$ & 42 & 126 \\
\hline $\mathrm{C} 09$ & 376 & 1 & 3 & 2 & $86 \mathrm{~b}$ & $50 \mathrm{ab}$ & $151 \mathrm{~cd}$ & $9.0 \mathrm{~b}$ & $11.3 \mathrm{bc}$ & $1.67 \mathrm{bc}$ & 39 & 112 \\
\hline C07 & $524 \mathrm{a}$ & 2 & 2 & 2 & $116 \mathrm{a}$ & $54 \mathrm{a}$ & $174 \mathrm{~b}$ & $11.6 \mathrm{a}$ & $23.0 \mathrm{a}$ & $2.00 \mathrm{~b}$ & 39 & 124 \\
\hline $\mathrm{C} 013$ & $404 \mathrm{~b}$ & 2 & 2 & 2 & $75 \mathrm{bc}$ & $43 \mathrm{c}$ & $144 \mathrm{de}$ & $11.2 \mathrm{a}$ & $12.6 \mathrm{bc}$ & $1.97 \mathrm{~b}$ & 23 & 121 \\
\hline $\mathrm{C} 014$ & $343 c$ & 2 & 3 & 2 & $85 \mathrm{~b}$ & $34 \mathrm{~d}$ & $201 \mathrm{a}$ & $10.0 \mathrm{a}$ & $6.8 \mathrm{~d}$ & $1.27 \mathrm{~cd}$ & 31 & 191 \\
\hline C016 & $380 \mathrm{bc}$ & 2 & 1 & 2 & 79 bc & $42 \mathrm{c}$ & $169 \mathrm{bc}$ & $10.7 \mathrm{a}$ & $13.1 \mathrm{bc}$ & $3.07 \mathrm{a}$ & 28 & 130 \\
\hline C018 & $371 \mathrm{bc}$ & 2 & 1 & 2 & $66 \mathrm{c}$ & $40 \mathrm{c}$ & $173 \mathrm{~b}$ & $10.9 \mathrm{a}$ & $13.3 \mathrm{~b}$ & $2.97 \mathrm{a}$ & 23 & 104 \\
\hline
\end{tabular}

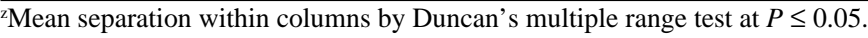

${ }^{y}$ Shape: $1=$ deeply serrated; $2=$ serrated. Gloss: $1=$ very glossy; $2=$ glossy; $3=$ dull. Color: $1=$ deep green; $2=$ green; $3=$ light green.

${ }^{\mathrm{x}}$ Weeks after seeding. 